\title{
Synthesis and anion binding properties of phthalimide-containing corona[6]arenes
}

\author{
Meng-Di Gu, Yao Lu and Mei-Xiang Wang *
}

\author{
Full Research Paper \\ Address: \\ MOE Key Laboratory of Bioorganic Phosphorous Chemistry and \\ Chemical Biology, Department of Chemistry, Tsinghua University, \\ Beijing 100084, China \\ Email: \\ Mei-Xiang Wang* - wangmx@mail.tsinghua.edu.cn \\ * Corresponding author \\ Keywords: \\ anion- $\Pi$ interactions; coronarenes; host-guest complexation; \\ $\mathrm{N}$-functionalized phthalimides; $\mathrm{O}_{6}$-corona[3]arene[3]tetrazines
}

Beilstein J. Org. Chem. 2019, 15, 1976-1983.

doi:10.3762/bjoc. 15.193

Received: 05 May 2019

Accepted: 06 August 2019

Published: 21 August 2019

This article is part of the thematic issue "Novel macrocycles - and old ones doing new tricks".

Guest Editor: W. Jiang

(C) 2019 Gu et al.; licensee Beilstein-Institut.

License and terms: see end of document.

\begin{abstract}
Functionalized $\mathrm{O}_{6}$-corona[3] arene[3]tetrazines were synthesized efficiently and conveniently by means of a macrocyclic condensation reaction between $N$-functionalized 3,6-dihydroxyphthalimides and 3,6-dichlorotetrazine under mild conditions in a one-pot reaction manner. The novel macrocycles exist as a mixture of rapidly interconvertible conformers in solution while in the solid state they adopt the conformation in which three phthalimide units are cis,trans-orientated. Acting as electron-deficient macrocyclic hosts, the synthesized $\mathrm{O}_{6}$-corona[3] arene[3]tetrazines self-regulated conformational structures to complex anions in the gas phase and in the solid state owing to the anion- $\pi$ noncovalent interactions between anions and the tetrazine rings.
\end{abstract}

\section{Introduction}

Synthetic macrocycles $[1,2]$ are always attractive and important because they are unique molecular systems to study molecular recognition and the nature of noncovalent interactions. Functional macrocycles also provide essential components for the fabrication or assembly of sophisticated (supra)molecular structures [1-4], advanced materials [1,2,5-10] and machinery systems $[1,2,11,12]$. Moreover, the designed macrocycles are useful molecular tools in the investigation of supramolecular catalysis and reaction mechanisms [1,2,13-16].

Heteracalixaromatics or heteroatom-bridged calix(het)arenes [17-21] are synthetic macrocycles composed of heteroatoms and meta-(het)arenes in an alternative manner. Because of the interplay between heteroatoms and aromatic rings, heteracalixaromatics possess versatile molecular recognition properties and have found wide supramolecular applications. Very recently, we have devised coronarenes [22] simply through editing or varying the meta-substitution of arylenes within heteracalixaromatics into the para-substitution. In contrast to heteracalixaromatics which adopt generally 1,3-alternate conformations giving V-shaped cleft structures [17-21], the resulting coronarenes form, however, cylindroid cavities [22]. We have also shown that the combination of and the interplay between heteroatoms and para-(het)arylenes produce diverse 
macrocycles with coarse- and fine-tunable cavity shapes and sizes. The resulting coronarenes exhibit interesting molecular recognition properties towards anions, cations and electronneutral organic guests [22-31].

In our previous study we have developed an efficient protocol to synthesize oxygen and sulfur-linked corona $[m]$ arene $[n]$ tetrazines from aromatic diol and dithiol derivatives and 3,6-dichlorotetrazine, respectively, in a simply operational one-pot reaction fashion on the basis of a nucleophilic aromatic substitution reaction [23-31]. To prepare functionalized corona[6] arenes using diethyl terephthalate as a starting material, we observed, however, the formation of a mixture of macrocyclic isomers because of a high energy barrier for the rotation of diethyl terephthalate units through the corona[6]arene macrocyclic annulus $[23,24]$. To circumvent the formation of structural isomers arising from the restricted rotation of aromatic fragments though the macrocycle annulus, we selected in the current study 3,6-dihydroxyphthalimide derivatives as aromatic diols to construct functionalized $\mathrm{O}_{6}$-corona[3] arene[3]tetrazins. Being different from terephthalate in terms of substitution pattern, we envisioned that the phthalimide unit would flip freely owing to the less steric hindrance. In addition, $N$-substituted 3,6-dihydroxyphthalimide derivatives are accessible conveniently from the reaction between various commercially available functional primary amines and 3,6-dihydoxyphthalic anhydride. The ready availability of $N$-functionalized 3,6-dihydroxyphthalimides would therefore enable the construction of functionalized coronarene macrocycles. Moreover, the electronic feature of the phthalimide would render the resulting $\mathrm{O}_{6}$-corona[3] arene[3]tetrazines the electron-deficient hosts to form anion- $\pi$ complexes [32-47]. We report herein the synthesis, structure and anion recognition of phthalimide-containing corona[3]arene[3]tetrazines.

\section{Results and Discussion}

In the presence of diisopropylethylamine (DIPEA) as an acid scavenger, $N$-phenyl (1a), $N$-cyclohexyl (1b) and $N$ - $n$-hexyl (1c)-substituted 3,6-dihydroxyphthalimides were able to react efficiently with 3,6-dichlorotetrazine [48] (2) under very mild conditions. The one-pot macrocyclic condensation reaction went to completion within $0.5 \mathrm{~h}$ to afford the corresponding $\mathrm{O}_{6}$-corona[3] arene[3]tetrazines $\mathbf{3 a - c}$ as the only macrocyclic ring products in yields of $38 \%$ to $63 \%$. We then prepared $N$-allyl (1d), $N$-(2-(2-hydroxyethoxy)ethyl (1e) and $N$-(2-(3-(4(trifluoromethyl)phenyl)ureido)ethyl) (1f) substituted 3,6-dihydroxyphthalimides to synthesize functionalized $\mathrm{O}_{6}$-coronarene macrocycles. Pleasingly, the 3,6-dihydroxyphthalimide substrates $1 \mathbf{d}$ and $1 \mathrm{e}$ underwent the same reaction to produce corona[6]arene macrocycles $\mathbf{3 d}$ and $\mathbf{3 e}$ in $54 \%$ and $35 \%$ yields, respectively. Corona[3] arene[3]tetrazine bearing even a urea group (3f) was synthesized analogously from the reaction of $\mathbf{1 f}$ with 2 when DABCO was employed as a base instead of DIPEA (Scheme 1). It was worth addressing that a chemical yield of $52 \%$ implied roughly a $90 \%$ yield for each step in these six-bond-forming synthesis. The high efficiency for the con-

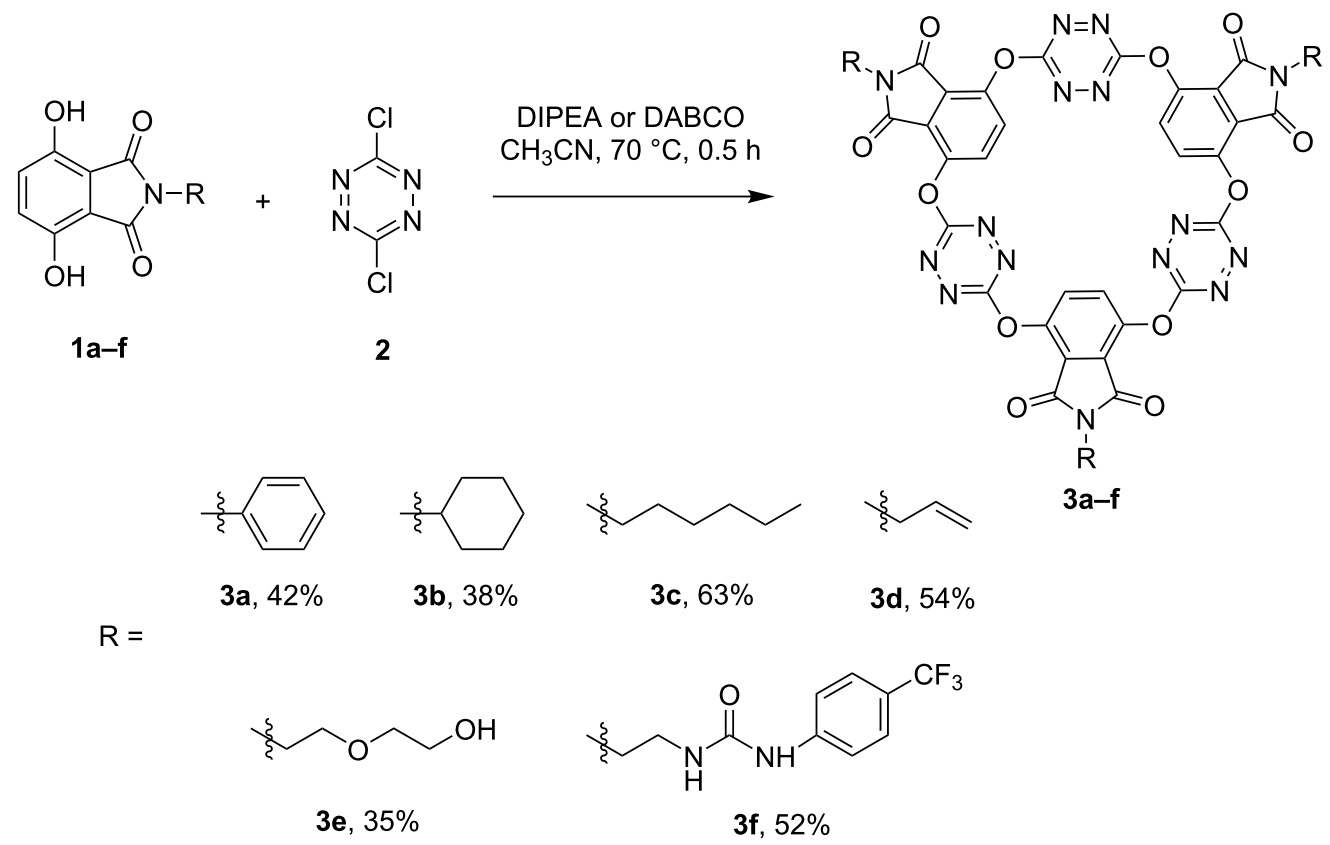

Scheme 1: Synthesis of phthalimide-containing $\mathrm{O}_{6}$-corona[3]arene[3]tetrazines. 
struction of a macrocyclic ring involving the formation of six new $\mathrm{C}-\mathrm{O}$ bonds between two reactants was noteworthy. The successful synthesis was most probably due to both the nature of dynamic chemical bonding between tetrazine and phenolic oxygen and the high stability of corona[6]arene macrocycle under the reaction conditions.

The spectroscopic data supported the macrocyclic structure of all products. To determine the structure beyond any doubt, and also to shed light on the conformation of phthalimide-containing $\mathrm{O}_{6}$-corona[6]arenes in the solid state, high quality single crystals of $\mathbf{3 a}$ were grown at room temperature from diffusion of diethyl ether vapor into the solution of $\mathbf{3 a}$ in acetonitrile. $\mathrm{X}$-ray diffraction analysis revealed that the macrocycle 3a adopted an interesting conformation. As depicted in Figure 1, it was evident that six bridging oxygen atoms formed roughly a plane. Interestingly, three tetrazine rings are procumbent on the plane while three phthalimide units were almost perpendicular to the plane. Judging from the bond lengths, all oxygen atoms in the linking positions tended to form conjugation with their adjacent tetrazine rings rather than with the phthalimide units. Most noticeably, the three phthalimide moieties are not cis-configured. The orientation of one phthalimide was just opposite to that of the other two phthalimide segments.

It is important to note that corona[3] arene[3]tetrazines $\mathbf{3}$ displayed only one set of proton and carbon signals in the ${ }^{1} \mathrm{H}$ and ${ }^{13} \mathrm{C}$ NMR spectra, respectively, in acetone- $d_{6}$ at room temperature (Figure 2). This is in sharp contradiction to $\mathrm{O}_{6}$-corona[3]arene[3]tetrazines composed of diethyl terephtha- late which give several sets of resonance peaks $[23,24]$. The observation of the single set of proton and carbon resonance signals of $\mathbf{3}$ indicated the presence of the conformer with high symmetry or most likely a mixture of conformers which underwent very fast interconversion relative to the NMR time scale. In comparison to diethyl terephthalate, a phthalimide segment even containing a large substituent on the imide nitrogen atom is able to flip readily between two sides of the plane defined by bridging oxygen atoms. The conformational fluxionality of the macrocyclic ring would be beneficial to molecular recognition.

To gain a deep insight into the redox properties of phthalimidebearing $\mathrm{O}_{6}$-corona[3] arene[3]tetrazines, a cyclic voltammogram $(\mathrm{CV})$ and a differential pulse voltammogram of $\mathbf{3 a}$ were recorded. As depicted in Figure 3, macrocycle 3a undergoes a reversible sequential one-electron redox process at $-811,-883$, -1871 , and $-2367 \mathrm{mV}$. The electrochemical result indicated the occurrence of electronic communication between aromatic rings. The potential for the first redox process $(-811 \mathrm{mV}) \mathrm{ob}-$ tained from CV and DPV revealed the electron deficiency of the macrocycle.

The resulting electron-deficient $\mathrm{O}_{6}$-corona[3] arene[3]tetrazines prompted us to investigate their anion binding behaviour. Taking compound 3a as a representative, we examined the interaction of macrocycles 3 with anions of tetra- $n$-butylammonium salts by means of electron spray ionization (ESI) mass spectrometry. It was found that the mass spectra of mixed samples of 3a with $n$ - $\mathrm{Bu}_{4} \mathrm{NX}$ gave ion peaks corresponding to $[\mathbf{3 a}-\mathrm{X}]^{-},\left[3 \mathbf{a}-n-\mathrm{Bu}_{4} \mathrm{~N}-2 \mathrm{X}\right]^{-}$and $\left[\mathbf{3 a}-n-2 \mathrm{Bu}_{4} \mathrm{~N}-3 \mathrm{X}\right]^{-}$com-
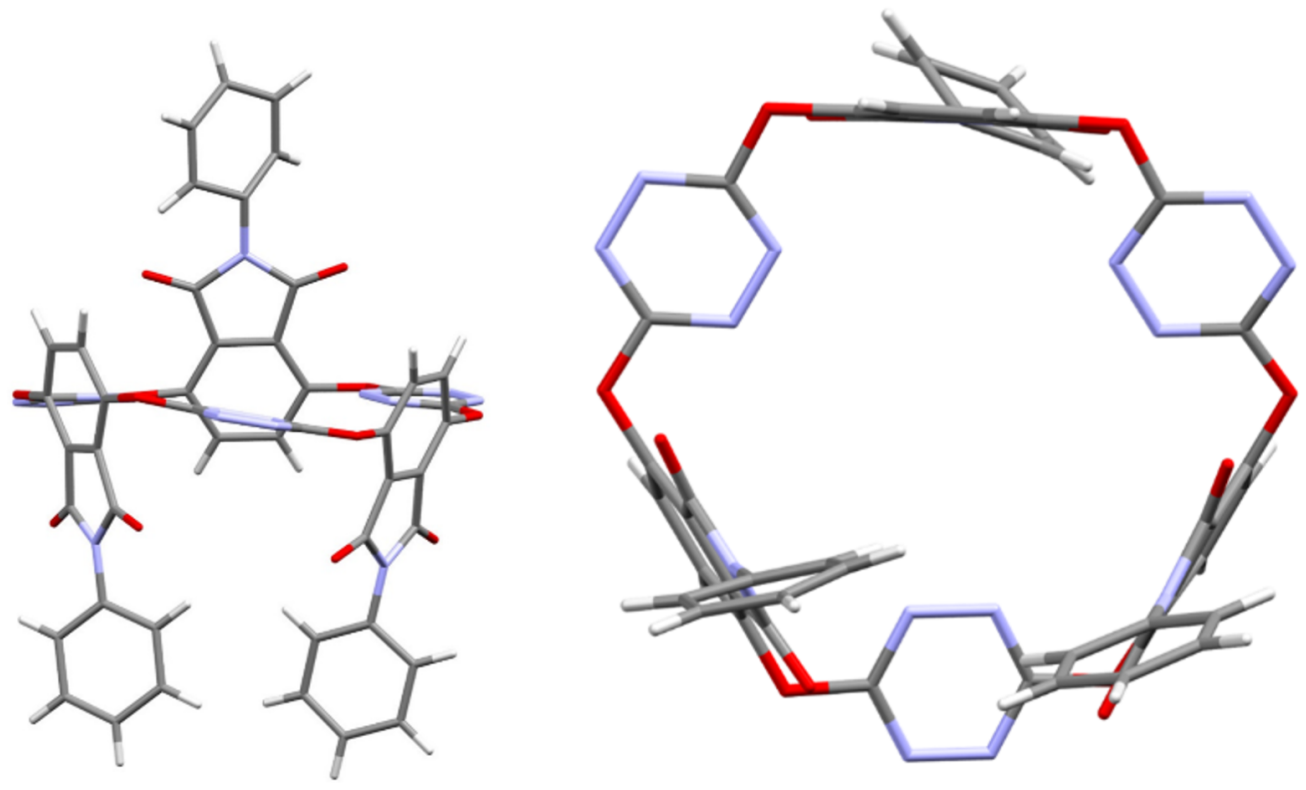

Figure 1: X-ray molecular structure of 3a (CCDC 1913907) with side (left) and top (right) views. All solvent molecules are omitted for clarity. 


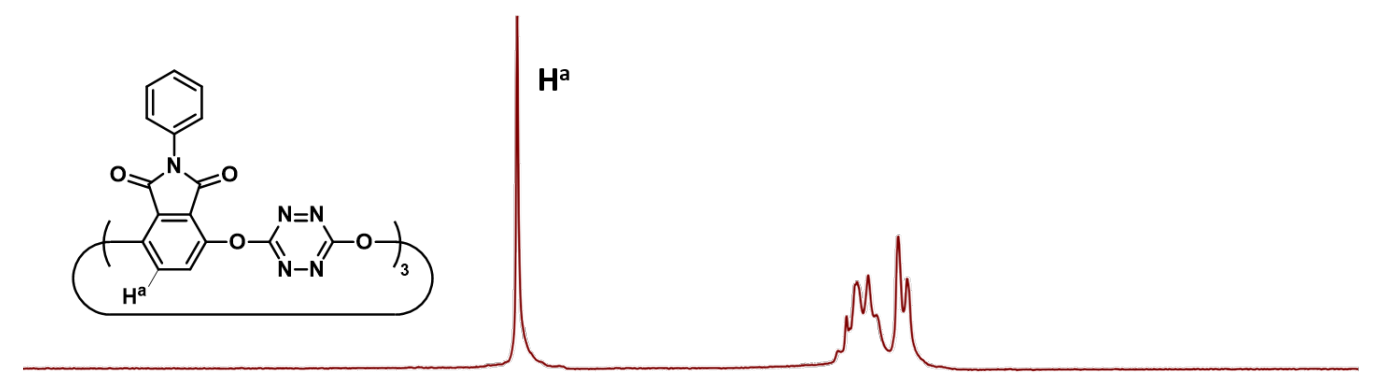

$\begin{array}{llllllllllllllllllllllllllllll}8.9 & 8.8 & 8.7 & 8.6 & 8.5 & 8.4 & 8.3 & 8.2 & 8.1 & 8.0 & 7.9 & 7.8 & 7.7 & 7.6 & 7.5 & 7.4 & 7.3 & 7.2 & 7.1 & 7.0 & 6.9 & 6.8 & 6.7 & 6.6 & 6.5 & 6.4 & 6.3\end{array}$

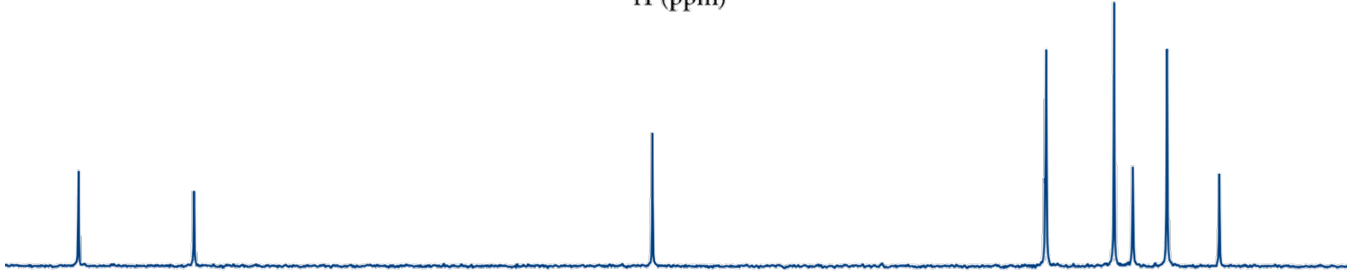

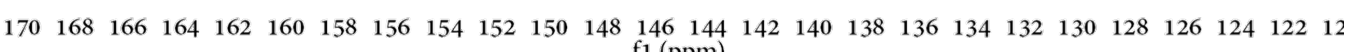
f1 (ppm)

Figure 2: ${ }^{1} \mathrm{H}$ (top) and ${ }^{13} \mathrm{C}$ (bottom) NMR spectra of $3 \mathbf{a}$ in acetone- $d_{6}$ at $25{ }^{\circ} \mathrm{C}$.
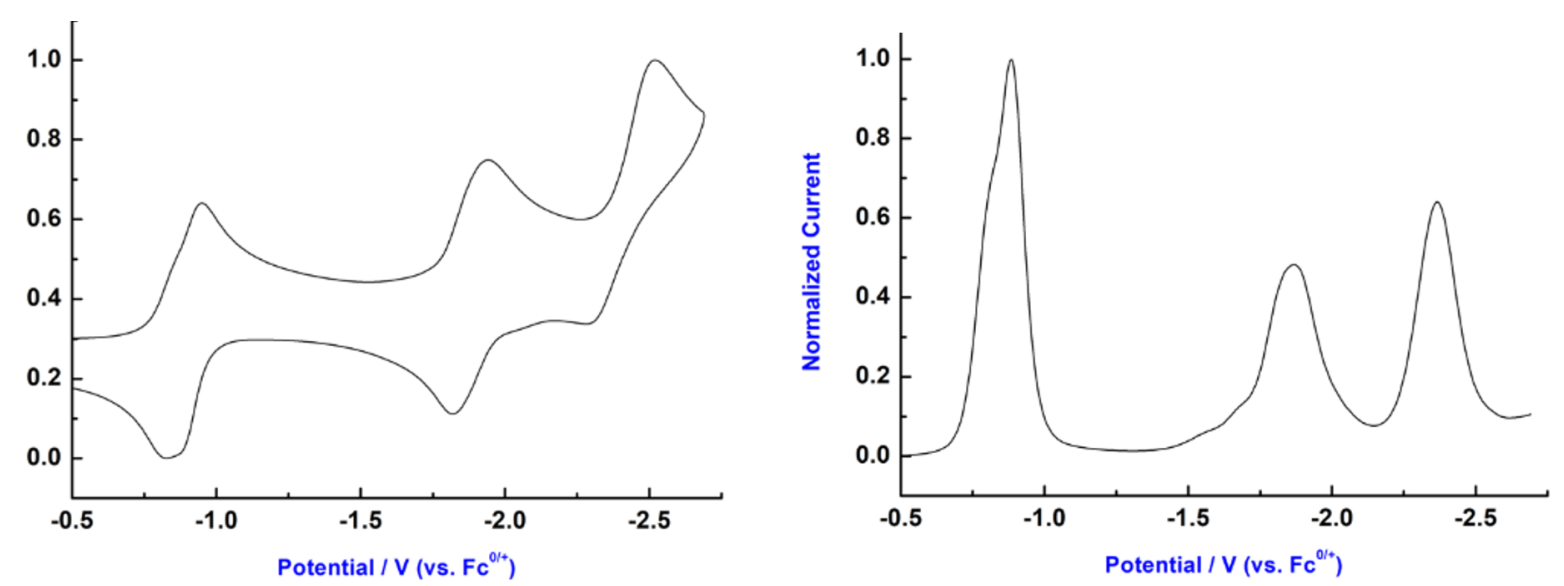

Figure 3: Normalized cyclic voltammograms (left) and differential pulse voltammograms (right) of 3a. CV and DPV were recorded (scan rate $100 \mathrm{mV} \cdot \mathrm{s}^{-1}$ ) using a glassy carbon electrode. All of the experiments were performed at $298 \mathrm{~K}$ in argon-purged MeCN solutions $0.5 \mathrm{mM}$ ) with $0.01 \mathrm{M}$ of $\left[\mathrm{Bu}_{4} \mathrm{~N}\right]^{+}\left[\mathrm{PF}_{6}\right]^{-}$as the supporting electrolyte. Potentials were recorded versus $\mathrm{Fc}^{+} / \mathrm{Fc}$.

plexes in which anions $\mathrm{X}^{-}$included spherical $\mathrm{Cl}^{-}, \mathrm{Br}^{-}, \mathrm{I}^{-}$, linear $\mathrm{SCN}^{-}$, planar triangle $\mathrm{NO}_{3}{ }^{-}$, tetrahedral $\mathrm{BF}_{4}{ }^{-}$and octahedral $\mathrm{PF}_{6}{ }^{-}$(see Supporting Information File 1). These results demonstrated clearly the outstanding ability of $\mathbf{3 a}$ to bind various anion species in gas phase. To our delight, host molecule 3a co-crystalized with $n$ - $\mathrm{Bu}_{4} \mathrm{NX}(\mathrm{X}=\mathrm{Cl}, \mathrm{Br})$ from diffusion of diethyl ether vapor into ethyl acetate solution at ambient temperature to give single crystals of the host-guest complexes
$\left(n-\mathrm{Bu}_{4} \mathrm{NX}\right)_{3}-\mathbf{3 a}(\mathrm{X}=\mathrm{Cl}, \mathrm{Br}) . \mathrm{X}$-ray crystallography then allowed us to understand the host-guest interactions at the molecular level. As illustrated in the molecular structures in Figure 4, above the centroid of each tetrazine ring there resided a chloride or a bromide. The distance of the anion to the centroid of tetrazine ranged from $3.060 \AA$ to $3.136 \AA\left(\mathrm{Cl}^{-}\right)$or from $3.194 \AA$ to $3.280 \AA\left(\mathrm{Br}^{-}\right)$. The location of anion above the tetrazine centroid with the shorter distance than the sum of van 


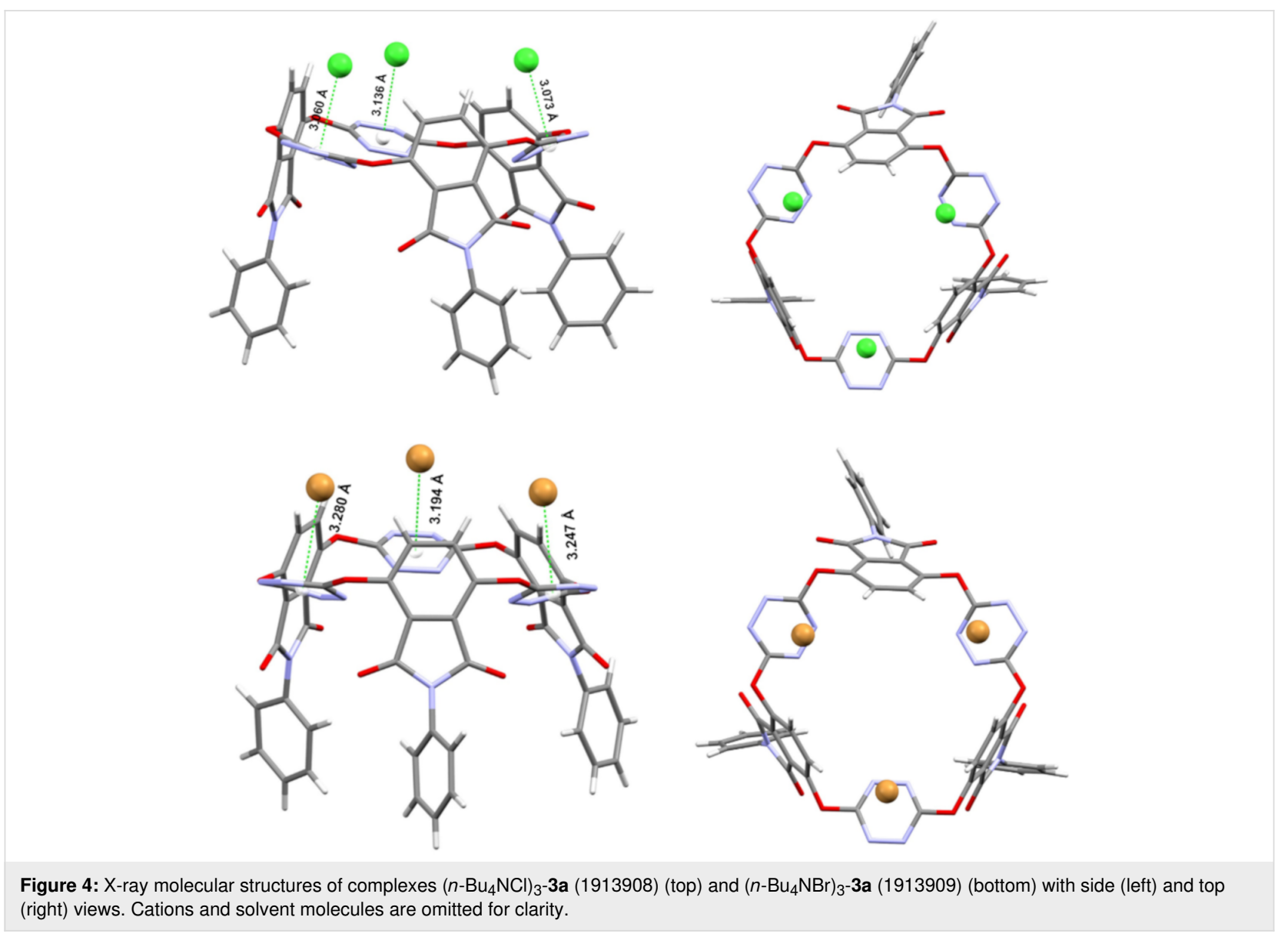

der Waals radius indicated explicitly the typical noncovalent anion $-\pi$ attraction. It is interesting to point out that in the host-guest complexes, all phthalimide units or their $N$-phenyl substituents became parallelly aligned (Figure 4). It seems that macrocyclic host $\mathbf{3 a}$ changed from its cis,trans-conformation (Figure 2) to the cis, cis one in order to best complex guest species. Another noteworthy structure feature was the deformation of all tetrazine rings. Upon complexation with a halide, the planar aromatic ring adopted a heavily pinched boat conformation, a result consistent with theoretical prediction [49]. We also examined the host-guest interaction in solution phase employing NMR and UV-vis spectroscopy and fluorescence technology. Unfortunately, titration of the host with the guest species did not cause appreciable spectral changes. Isotherm titration calorimetry (ITC) did not give satisfactory results either.

\section{Conclusion}

In summary, we have synthesized phthalimide-containing functionalized $\mathrm{O}_{6}$-corona[3]-arene[3]tetrazines by means of a onepot macrocyclic condensation reaction between $\mathrm{N}$-functionalized 3,6-dihydroxyphthalimides and 3,6-dichlorotetrazine. The unprecedented macrocycles exist as a mixture of rapidly interconvertible conformers in solution relative to the NMR time scale. The novel $\mathrm{O}_{6}$-corona[3] arene[3]tetrazines self-regulated conformational structures to complex anions in the gas phase and in the solid state owing to the anion- $\pi$ noncovalent interactions between anions and the tetrazine rings. The easy accessibility, cylindroid cavity and diverse functionality would engender phthalimide-containing functionalized $\mathrm{O}_{6}$-corona[3]arene[3]tetrazines a useful macrocyclic platform for the study of supramolecular chemistry. Applications of the phthalimidecontaining functionalized $\mathrm{O}_{6}$-corona[3]-arene[3]tetrazines are being actively perused and results will be reported in due course.

\section{Experimental}

General procedure for the synthesis of 3a-e. To a solution of DIPEA $(2.1 \mathrm{mmol})$ in acetonitrile $(150 \mathrm{~mL})$ which was preheated to $70{ }^{\circ} \mathrm{C}$ was added dropwise a solution of 3,6-dihydroxyphthalimide derivatives 1a-e (1 mmol) and 3,6-dichlorotetrazine $(2,1 \mathrm{mmol})$ in acetonitrile $(25 \mathrm{~mL})$ during $25 \mathrm{~min}$. After being stirred for another $5 \mathrm{~min}$, the reaction was quenched by cooling down the mixture to ambient temperature and adding water $(200 \mathrm{~mL})$. The resulting mixture was neutralized with dilute hydrochloric acid $(1 \mathrm{M})$ and extracted with EtOAc $(3 \times 150 \mathrm{~mL})$. The combined organic solution was washed with 
brine $(3 \times 200 \mathrm{~mL})$ and then dried over anhydrous $\mathrm{Na}_{2} \mathrm{SO}_{4}$. After filtration and concentration, the residue was chromatographed on a silica gel column using a mixture of DCM and EtOAc $(\mathrm{v} / \mathrm{v}=100: 1)$ as an eluent to give product 3a-e.

3a: $140 \mathrm{mg}$, yield $42 \%$, red solid, mp $275^{\circ} \mathrm{C}$ (decomp.); ${ }^{1} \mathrm{H}$ NMR (400 MHz, acetone- $\left.d_{6}, 25{ }^{\circ} \mathrm{C}\right) \delta 8.00(\mathrm{~s}, 6 \mathrm{H})$, 7.20-7.34 (m, 15H); ${ }^{13} \mathrm{C}$ NMR (101 MHz, acetone- $\left.d_{6}, 25{ }^{\circ} \mathrm{C}\right) \delta$ 168.8, 164.4, 147.1, 132.2, 132.1, 129.6, 128.8, 127.5, 125.6; IR $\left(\mathrm{KBr}, \mathrm{cm}^{-1}\right)$ v: $3078,1777,1724,1494,1384,1230,1115$, 955; HRMS-APCI: $[\mathrm{M}+\mathrm{H}]^{+}$calcd for $\mathrm{C}_{48} \mathrm{H}_{22} \mathrm{~N}_{15} \mathrm{O}_{12}$, 1000.1567; found, 1000.1553; anal. calcd for $\mathrm{C}_{48} \mathrm{H}_{21} \mathrm{~N}_{15} \mathrm{O}_{12}$ : C, 57.66; H, 2.12; N, 21.01; found: C, 57.71; H, 2.08; N, 20.70.

3b: $129 \mathrm{mg}$, yield $38 \%$, red solid, mp $275{ }^{\circ} \mathrm{C}$ (decomp.); ${ }^{1} \mathrm{H}$ NMR (400 MHz, MeCN-d $\left.d_{3}, 25{ }^{\circ} \mathrm{C}\right) \delta 7.72(\mathrm{~s}, 6 \mathrm{H})$, 3.77-3.70 (m, 3H), 1.83-1.76 (m,6H), 1.71-1.68 (m, 6H), $1.25-1.04(\mathrm{~m}, 9 \mathrm{H}) ;{ }^{13} \mathrm{C}$ NMR $\left(101 \mathrm{MHz}, \mathrm{MeCN}-d_{3}, 25{ }^{\circ} \mathrm{C}\right) \delta$ $168.6,165.5,146.4,131.5,125.5,52.0,30.0,26.5,25.8$; IR $\left(\mathrm{KBr}, \mathrm{cm}^{-1}\right)$ v: $2934,2858,1772,1715,1382,1228,955$; HRMS-APCI: $[\mathrm{M}+\mathrm{H}]^{+}$calcd for $\mathrm{C}_{48} \mathrm{H}_{40} \mathrm{~N}_{15} \mathrm{O}_{12}, 1018.2975$; found, 1018.2954; anal. calcd for $\mathrm{C}_{48} \mathrm{H}_{39} \mathrm{~N}_{15} \mathrm{O}_{12}$ : C, 56.64; $\mathrm{H}$, 3.86; N, 20.64; found: C, 56.51; H, 3.83; N, 20.24.

3c: $215 \mathrm{mg}$, yield $63 \%$, red solid, mp $275^{\circ} \mathrm{C}$ (decomp.); ${ }^{1} \mathrm{H}$ NMR (400 MHz, $\left.\mathrm{CDCl}_{3}, 25^{\circ} \mathrm{C}\right) \delta 7.63(\mathrm{~s}, 6 \mathrm{H}), 3.38(\mathrm{t}$, $J=6.8 \mathrm{~Hz}, 6 \mathrm{H}), 1.54-1.48(\mathrm{~m}, 6 \mathrm{H}), 1.23-1.19(\mathrm{~m}, 18 \mathrm{H}), 0.82$ $(\mathrm{t}, J=6.8 \mathrm{~Hz}, 9 \mathrm{H}) ;{ }^{13} \mathrm{C} \mathrm{NMR}\left(101 \mathrm{MHz}, \mathrm{CDCl}_{3}, 25^{\circ} \mathrm{C}\right) \delta$ 167.4, 164.4, 145.5, 130.1, 124.7, 38.6, 31.2, 29.7, 28.1, 26.4, 22.4, 13.9; IR $\left(\mathrm{KBr}, \mathrm{cm}^{-1}\right)$ v: 3081, 2931, 2859, 1774, 1717, 1494, 1440, 1417, 1379, 1227, 1065, 954; HRMS-APCI: $[\mathrm{M}+\mathrm{H}]^{+}$calcd for $\mathrm{C}_{48} \mathrm{H}_{46} \mathrm{~N}_{15} \mathrm{O}_{12}, 1024.3445$; found, 1024.3437; anal. calcd for $\mathrm{C}_{48} \mathrm{H}_{45} \mathrm{~N}_{15} \mathrm{O}_{12}$ acetone: $\mathrm{C}, 56.61 ; \mathrm{H}$, 4.75 ; N, 19.42; found: C, 56.17; H, 4.66; N, 19.34 .

3d: $160 \mathrm{mg}$, yield $54 \%$, red solid, $\mathrm{mp}>300{ }^{\circ} \mathrm{C}$; ${ }^{1} \mathrm{H}$ NMR $\left(400 \mathrm{MHz}, \mathrm{CDCl}_{3}, 25^{\circ} \mathrm{C}\right) \delta 7.66(\mathrm{~s}, 6 \mathrm{H}), 5.70-5.64(\mathrm{~m}, 3 \mathrm{H})$, $5.12-5.07(\mathrm{~m}, 6 \mathrm{H}), 4.00(\mathrm{~d}, J=6.0 \mathrm{~Hz}, 3 \mathrm{H}) ;{ }^{13} \mathrm{C} \mathrm{NMR}$ $\left(101 \mathrm{MHz}, \mathrm{CDCl}_{3}, 25^{\circ} \mathrm{C}\right) \delta 167.4,163.8,145.6,130.4,130.2$, 124.6, 118.6, 40.5; IR (KBr, cm $\left.{ }^{-1}\right)$ v: $3288,1781,1725,1428$, 1380, 1344, 1229, 1229, 1122, 954, 924; HRMS-APCI: $[\mathrm{M}+\mathrm{H}]^{+}$calcd for $\mathrm{C}_{39} \mathrm{H}_{22} \mathrm{~N}_{15} \mathrm{O}_{12}, 892.1567$; found, 892.1563. anal. calcd for $\mathrm{C}_{39} \mathrm{H}_{21} \mathrm{~N}_{15} \mathrm{O}_{12} \cdot 0.5 \mathrm{H}_{2} \mathrm{O}$ : C, 52.01; H, 2.46; N, 23.33; found: C, 52.39; H, 2.11; N, 22.94.

3e: $121 \mathrm{mg}$, yield $35 \%$, red solid, mp $182-186{ }^{\circ} \mathrm{C} ;{ }^{1} \mathrm{H}$ NMR (400 MHz, acetone- $\left.d_{6}, 25^{\circ} \mathrm{C}\right) \delta 7.95(\mathrm{~s}, 6 \mathrm{H}), 3.50-3.55(\mathrm{~m}$, $12 \mathrm{H}), 3.34-3.41(\mathrm{~m}, 12 \mathrm{H}), 2.83(\mathrm{~s}, 3 \mathrm{H}) ;{ }^{13} \mathrm{C} \mathrm{NMR}(101 \mathrm{MHz}$, acetone- $\left.d_{6}, 25^{\circ} \mathrm{C}\right) \delta 168.7,165.3,146.6,131.8,125.7,73.2$, 67.8, 61.8, 38.6; IR (KBr, cm $\left.{ }^{-1}\right)$ v: 3472, 1776, 1716, 1382, 1228, 956; HRMS-APCI: $[\mathrm{M}+\mathrm{Na}]^{+}$calcd for $\mathrm{C}_{42} \mathrm{H}_{33} \mathrm{~N}_{15} \mathrm{O}_{18}$,
1058.2020; found, 1058.2029; anal. calcd for $\mathrm{C}_{42} \mathrm{H}_{33} \mathrm{~N}_{15} \mathrm{O}_{18} \cdot \mathrm{H}_{2} \mathrm{O}: \mathrm{C}, 48.87 ; \mathrm{H}, 3.35 ; \mathrm{N}, 19.94$; found: $\mathrm{C}$, 48.12; H, 3.01; N, 19.90 .

Synthesis of 3f: To a solution of DABCO $(2.1 \mathrm{mmol})$ in acetonitrile $(150 \mathrm{~mL})$ which was pre-heated to $70{ }^{\circ} \mathrm{C}$ was added dropwise a solution of $\mathbf{1 f}(1 \mathrm{mmol})$ and 3,6-dichlorotetrazine (2, $\mathrm{mmol})$ in acetonitrile $(25 \mathrm{~mL})$ during $25 \mathrm{~min}$. After being stirred for another $5 \mathrm{~min}$, the reaction was quenched by cooling the mixture down to ambient temperature and adding water $(200 \mathrm{~mL})$. The resulting mixture was neutralized with dilute hydrochloric acid (1 M) and extracted with EtOAc $(3 \times 150 \mathrm{~mL})$. The combined organic solution was washed with brine $(3 \times 200 \mathrm{~mL})$ and then dried over anhydrous $\mathrm{Na}_{2} \mathrm{SO}_{4}$. After filtration and concentration, the residue was chromatographed on a silica gel column using a mixture of DCM and EtOAc ( $/ \mathrm{v} / \mathrm{v}=25: 1)$ as an eluent to give product $3 \mathbf{f}(261 \mathrm{mg}$, yield 52\%) as a red solid, mp 207-210 ${ }^{\circ} \mathrm{C}$; ${ }^{1} \mathrm{H}$ NMR (400 MHz, DMSO- $\left.d_{6}, 25{ }^{\circ} \mathrm{C}\right) \delta 8.98(\mathrm{~s}, 3 \mathrm{H}), 7.88(\mathrm{~s}, 5 \mathrm{H}), 7.53(\mathrm{~s}, 12 \mathrm{H})$, $6.23(\mathrm{t}, J=5.7 \mathrm{~Hz}, 3 \mathrm{H}), 3.36(\mathrm{~m}, 6 \mathrm{H}), 3.01(\mathrm{~m}, 6 \mathrm{H}), 1.60(\mathrm{t}$, $J=6.4 \mathrm{~Hz}, 6 \mathrm{H}) ;{ }^{19} \mathrm{~F}$ NMR $\left(376 \mathrm{MHz}, \mathrm{DMSO}-d_{6}, 25^{\circ} \mathrm{C}\right) \delta$ $59.8 ;{ }^{13} \mathrm{C}$ NMR $\left(101 \mathrm{MHz}, \mathrm{MeCN}-d_{3}, 25{ }^{\circ} \mathrm{C}\right) \delta 167.1,164.5$, $154.8,145.0,144.2,131.2,125.9,124.7\left(\mathrm{q},{ }^{1} J(\mathrm{C}, \mathrm{F})=\right.$ $271.6 \mathrm{~Hz}), 124.5,120.9\left(\mathrm{q},{ }^{2} J(\mathrm{C}, \mathrm{F})=31.8 \mathrm{~Hz}\right), 117.1,36.5$, $35.5,28.2$; IR $\left(\mathrm{KBr}, \mathrm{cm}^{-1}\right)$ v: 3372, 3080, 2937, 1775, 1717, 1603, 1545, 1382, 1325, 1228, 1113, 1066. HRMS-APCI: $[\mathrm{M}-\mathrm{H}]^{-}$calcd for $\mathrm{C}_{63} \mathrm{H}_{41} \mathrm{~N}_{21} \mathrm{O}_{15} \mathrm{~F}_{9}, 1502.2953$; found, 1502.2972; anal. calcd for $\mathrm{C}_{63} \mathrm{H}_{42} \mathrm{~F}_{9} \mathrm{~N}_{21} \mathrm{O}_{15} \cdot \mathrm{H}_{2} \mathrm{O}: \mathrm{C}, 49.71 ; \mathrm{H}$, $2.91 ; \mathrm{N}, 19.32$. found: C, 49.42; H, 3.04; N, 19.01 .

\section{Supporting Information}

\section{Supporting Information File 1}

Experimental procedures, characterization of products and copies of mass and NMR spectra.

[https://www.beilstein-journals.org/bjoc/content/ supplementary/1860-5397-15-193-S1.pdf]

\section{Acknowledgements}

We thank the National Natural Science Foundation of China [grant numbers 21732004, 21821001] and Tsinghua University Initiative Scientific Research Program for financial support.

\section{ORCID ${ }^{\circledR}$ iDs}

Mei-Xiang Wang - https://orcid.org/0000-0001-7112-0657

\section{References}

1. Atwood, J.; Gokel, G. W.; Barbour, L., Eds. Comprehensive Supramolecular Chemistry II, 2nd ed.; Elsevier: Amsterdam, Netherlands, 2017. 
2. Lehn, J.-M.; Atwood, J. L.; Davies, J. E. D.; MacNicol, D. D.; Vögtle, F., Eds. Comprehensive Supramolecular Chemistry; Pergamon: Oxford, United Kingdom, 1996.

3. Wang, Q.-Q.; Luo, N.; Wang, X.-D.; Ao, Y.-F.; Chen, Y.-F.; Liu, J.-M.; Su, C.-Y.; Wang, D.-X.; Wang, M.-X. J. Am. Chem. Soc. 2017, 139, 635-638. doi:10.1021/jacs.6b12386

4. Jiang, B.; Wang, W.; Zhang, Y.; Lu, Y.; Zhang, C.-W.; Yin, G.-Q.; Zhao, X.-L.; Xu, L.; Tan, H.; Li, X.; Jin, G.-X.; Yang, H.-B. Angew. Chem., Int. Ed. 2017, 56, 14438-14442. doi:10.1002/anie.201707209

5. Liu, Z.; Nalluri, S. K. M.; Stoddart, J. F. Chem. Soc. Rev. 2017, 46, 2459-2478. doi:10.1039/c7cs00185a

6. Ogoshi, T.; Yamagishi, T.-a.; Nakamoto, Y. Chem. Rev. 2016, 116, 7937-8002. doi:10.1021/acs.chemrev.5b00765

7. Shetty, D.; Khedkar, J. K.; Park, K. M.; Kim, K. Chem. Soc. Rev. 2015, 44, 8747-8761. doi:10.1039/c5cs00631g

8. Jie, K.; Zhou, Y.; Yao, Y.; Huang, F. Chem. Soc. Rev. 2015, 44, 3568-3587. doi:10.1039/c4cs00390j

9. Han, Y.; Meng, Z.; Ma, Y.-X.; Chen, C.-F. Acc. Chem. Res. 2014, 47, 2026-2040. doi:10.1021/ar5000677

10. Wu, G.-Y.; Chen, L.-J.; Xu, L.; Zhao, X.-L.; Yang, H.-B. Coord. Chem. Rev. 2018, 369, 39-75. doi:10.1016/j.ccr.2018.05.009

11. Sauvage, J.-P. Angew. Chem., Int. Ed. 2017, 56, 11080-11093. doi:10.1002/anie.201702992

12. Stoddart, J. F. Angew. Chem., Int. Ed. 2017, 56, 11094-11125. doi:10.1002/anie.201703216

13. Neel, A. J.; Hilton, M. J.; Sigman, M. S.; Toste, F. D. Nature 2017, 543, 637-646. doi:10.1038/nature21701

14. Galan, A.; Ballester, P. Chem. Soc. Rev. 2016, 45, 1720-1737. doi:10.1039/c5cs00861a

15. Zhang, H.; Yao, B.; Zhao, L.; Wang, D.-X.; Xu, B.-Q.; Wang, M.-X. J. Am. Chem. Soc. 2014, 136, 6326-6332. doi:10.1021/ja412615h

16. Zhang, Q.; Liu, Y.; Wang, T.; Zhang, X.; Long, C.; Wu, Y.-D.; Wang, M.-X. J. Am. Chem. Soc. 2018, 140, 5579-5587. doi:10.1021/jacs.8b01896

17. Wang, M.-X. Chem. Commun. 2008, 4541. doi:10.1039/b809287g

18. Wang, M.-X. Acc. Chem. Res. 2012, 45, 182-195. doi:10.1021/ar200108c

19. Maes, W.; Dehaen, W. Chem. Soc. Rev. 2008, 37, 2393. doi:10.1039/b718356a

20. Tsue, H.; Ishibashi, K.; Tamura, R. Top. Heterocycl. Chem. 2008, 17, 73. doi:10.1007/7081_2007_094

21. Neri, P.; Sessler, J. L.; Wang, M.-X., Eds. Calixarenes and Beyond; Springer: Berlin, Germany, 2016. doi:10.1007/978-3-319-31867-7 Chapters 14-16 and 18.

22. Wang, M.-X. Sci. China: Chem. 2018, 61, 993-1003. doi:10.1007/s11426-018-9328-8

23. Guo, Q.-H.; Fu, Z.-D.; Zhao, L.; Wang, M.-X. Angew. Chem., Int. Ed. 2014, 53, 13548-13552. doi:10.1002/anie.201407670

24. Guo, Q.-H.; Zhao, L.; Wang, M.-X. Angew. Chem., Int. Ed. 2015, 54, 8386-8389. doi:10.1002/anie.201503179

25. Fu, Z.-D.; Guo, Q.-H.; Zhao, L.; Wang, D.-X.; Wang, M.-X. Org. Lett. 2016, 18, 2668-2671. doi:10.1021/acs.orglett.6b01112

26. Wu, Z.-C.; Guo, G.-H.; Wang, M.-X. Angew. Chem., Int. Ed. 2017, 56, 7151. doi:10.1002/anie.201703008

27. Liu, H.-B.; Zhang, Q.; Wang, M.-X. Angew. Chem., Int. Ed. 2018, 57, 6536. doi:10.1002/anie.201802020

28. Guo, Q.-H.; Zhao, L.; Wang, M.-X. Chem. - Eur. J. 2016, 22 , 6947-6955. doi:10.1002/chem.201600462
29. Lu, Y.; Fu, Z.-D.; Guo, Q.-H.; Wang, M.-X. Org. Lett. 2017, 19, 1590-1593. doi:10.1021/acs.orglett.7b00409

30. Ren, W.-S.; Zhao, L.; Wang, M.-X. Org. Lett. 2016, 18, 3126-3129. doi:10.1021/acs.orglett.6b01330

31. Lu, Y.; Liang, D.-D.; Fu, Z.-D.; Guo, Q.-H.; Wang, M.-X. Chin. J. Chem 2018, 36, 630-634. doi:10.1002/cjoc.201800131

32. Gamez, P. Inorg. Chem. Front. 2014, 1, 35-43. doi:10.1039/c3qi00055a

33. Bauzá, A.; Mooibroek, T. J.; Frontera, A. ChemPhysChem 2015, 16 , 2496-2517. doi:10.1002/cphc.201500314

34. Zhao, Y.; Cotelle, Y.; Liu, L.; López-Andarias, J.; Bornhof, A.-B.; Akamatsu, M.; Sakai, N.; Matile, S. Acc. Chem. Res. 2018, 51 , 2255-2263. doi:10.1021/acs.accounts.8b00223

35. Tuo, D.-H.; Liu, W.; Wang, X.-Y.; Wang, X.-D.; Ao, Y.-F.; Wang, Q.-Q.; Li, Z.-Y.; Wang, D.-X. J. Am. Chem. Soc. 2019, 141, 1118-1125. doi:10.1021/jacs.8b12018

36. Luo, J.; Ao, Y.-F.; Wang, Q.-Q.; Wang, D.-X. Angew. Chem., Int. Ed. 2018, 57, 15827-15831. doi:10.1002/anie.201810836

37. He, Q.; Ao, Y.-F.; Huang, Z.-T.; Wang, D.-X. Angew. Chem., Int. Ed. 2015, 54, 11785-11790. doi:10.1002/anie.201504710

38. Wang, D.-X.; Zheng, Q.-Y.; Wang, Q.-Q.; Wang, M.-X. Angew. Chem., Int. Ed. 2008, 47, 7485. doi:10.1002/anie.200801705

39. Wang, D.-X.; Wang, M.-X. J. Am. Chem. Soc. 2013, 135, 892-897. doi:10.1021/ja310834w

40. Wang, D.-X.; Wang, Q.-Q.; Han, Y.; Wang, Y.; Huang, Z.-T.; Wang, M.-X. Chem. - Eur. J. 2010, 16, 13053-13057. doi:10.1002/chem.201002307

41. Chifotides, H. T.; Schottel, B. L.; Dunbar, K. R. Angew. Chem., Int. Ed. 2010, 49, 7202. doi:10.1002/anie.201001755

42. Rosokha, Y. S.; Lindeman, S. V.; Rosokha, S. V.; Kochi, J. K. Angew. Chem., Int. Ed. 2004, 43, 4650-4652. doi:10.1002/anie.200460337

43. Adriaenssens, L.; Gil-Ramírez, G.; Frontera, A.; Quiñonero, D.; Escudero-Adán, E. C.; Ballester, P. J. Am. Chem. Soc. 2014, 136, 3208-3218. doi:10.1021/ja412098v

44. Zhang, J.; Zhou, B.; Sun, Z.-R.; Wang, X.-B. Phys. Chem. Chem. Phys. 2015, 17, 3131-3141. doi:10.1039/c4cp04687k

45. Anstöter, C. S.; Rogers, J. P.; Verlet, J. R. R. J. Am. Chem. Soc. 2019, 141, 6132-6135. doi:10.1021/jacs.9b01345

46. Xi, J.; Xu, X. Phys. Chem. Chem. Phys. 2016, 18, 6913-6924. doi:10.1039/c5cp08065g

47. Zheng, X.; Shuai, Z.; Wang, D. J. Phys. Chem. A 2013, 117, 3844-3851. doi:10.1021/jp3113478

48. Clavier, G.; Audebert, P. Chem. Rev. 2010, 110, 3299-3314. doi:10.1021/cr900357e

49. Garau, C.; Quiñonero, D.; Frontera, A.; Costa, A.; Ballester, P.; Deyà, P. M. Chem. Phys. Lett. 2003, 370, 7-13. doi:10.1016/s0009-2614(03)00020-4 


\section{License and Terms}

This is an Open Access article under the terms of the Creative Commons Attribution License (http://creativecommons.org/licenses/by/4.0). Please note that the reuse, redistribution and reproduction in particular requires that the authors and source are credited.

The license is subject to the Beilstein Journal of Organic Chemistry terms and conditions:

(https://www.beilstein-journals.org/bjoc)

The definitive version of this article is the electronic one which can be found at:

doi:10.3762/bjoc. 15.193 